\title{
Forage development through farmer participatory research for the sustainability of smallholder dairy farmers
}

\begin{abstract}
This paper describes the forage development through farmer participatory research and enhancing farm profitability by establishing an innovative informal strategy of developing village-based forage seed enterprises (VBFSEs) of Berseem clover (Trifolium alexandrinum L.) in Pakistan. The involvement of farmers in varietal selection and development is very important in ensuring the forage development and adoption of improved forage varieties in commercial production systems for increasing livestock productivity to enhance smallholder farmer's livelihoods.
\end{abstract}

Keywords: forage production, varietal selection and evaluation, farm profitability, rural development

\author{
Volume 5 Issue 4 - 2017 \\ Tufail MS,' Krebs G,' Southwell A, ${ }^{2}$ Piltz J, ${ }^{3}$ \\ Wynn PC' \\ 'School of Animal and Veterinary Sciences, Charles Sturt \\ University, Australia \\ ${ }^{2}$ School of Agriculture and Wine Sciences, Charles Sturt \\ University, Australia \\ ${ }^{3}$ Department of Primary Industries, Wagga Wagga Agricultural \\ Institute, Australia
}

\begin{abstract}
Correspondence: Tufail, Muhammad Shoaib, School of Animal and Veterinary Sciences, Charles Sturt University, Wagga Wagga NSW 2678 Australia, Tel +6I 269332 959,

Email mtufail@csu.edu.au
\end{abstract}

Received: May 17, 2017 | Published: June 26, 2017

\section{Introduction}

Crop-livestock production is an integral part of the mixed farming systems in Pakistan and characterised by small-scale subsistence farming to produce food for meeting daily household dietary requirements. However, livestock productivity is very low and restricted by the lack of quality fodder due to unavailability of seed. ${ }^{1}$ The farmer participatory research approach elevates local knowledge to the role of science in food security by increasing productivity at the farm level. Collaborative experimentation with farmers can result in the identification of the better varieties (through selection), leading to increased forage yield and quality. ${ }^{2}$ Moreover, on-farm testing, selection and evaluation of improved varieties can result to the farmer-based seed production. Farmer seed enterprises serve markets through linking research and the commercial sector for the timely availability of good quality seed. Therefore, VBFSE is a potentially viable, alternative seed supply system where formal seed supply is a limiting factor for smallholder dairy farmers.

\section{Materials and methods}

On-farm research trials were conducted in Pakistan during 20122014, to establish the most appropriate seed source of Berseem clover with the aim of forage development to achieve maximum forage and seed production at farm level. A randomised complete block design and five replicates were used, where each research site was considered as replication. The three sources of Berseem clover were Farmer seed (FS), Market seed (MS) and Research station seed (RS). Data was recorded on green forage (GF), dry matter $(\mathrm{DM})(\mathrm{t} / \mathrm{ha})$ and seed yields $(\mathrm{SY})(\mathrm{kg} / \mathrm{ha})$ after multiple forage cuttings $(65,110$ and 150days after sowing). Additionally, the major indicators of fodder nutrition were measured through near-infrared reflectance (NIR) to access the forage nutrition. The data were analysed with the linear mixed model (ASREML) by using GenStat ${ }^{\circledR}\left(17^{\text {th }}\right.$ edition) at $5 \%$ level of significance to compare treatment means. Partial budget analyses were also carried out using Microsoft Excel $2013^{\circledR}$ windows software to estimate the economic benefits.

\section{Results and discussion}

The different seed sources significantly $(P<0.05)$ affected the forage and seed yields and forage quality parameters (Table 1) across all the experimental sites. The mean DM, GF and seed yields of 8.39, $60.79 \mathrm{t} / \mathrm{ha}$ and $580 \mathrm{~kg} / \mathrm{ha}$, respectively were produced by using RS as compared to FS or MS. The average nutritive value of the forage also significantly $(P<0.05)$ affected by the seed source. However, WSC did not vary $(P>0.05)$ between the different seed sources. Overall, RS produced better quality forage of Berseem clover compared to FS and MS (Table 1). The analysis further revealed that average net incomes of 279690 Rs/ha (2715 US\$/ha) was earned through VBFSE development of Berseem clover in the study area having more returns (236\%) as compared to conventionally grown forage (65\%).

Seed quality of Berseem clover directly affects crop yields through plant growth, and indirectly influences the nutritive value of the forage. The frequent cuttings can be used to manipulate the distribution of DM, subsequently impacting on DM and seed yields of Berseem clover ${ }^{3}$ which was in agreement to the results reported in the present study. Smallholder farmers are often reluctant in adopting the improved technologies related to genetic improvement and production of fodder crops. ${ }^{4}$ David $^{2}$ identified the introduction of improved varieties in smallholder farming systems has been found to not only significantly increase yields but also to result in the establishment of new markets for both the surplus forage and seed. The majority of the smallholder farmers are the primary source of local varieties germplasm and participatory approach has proved to be a workable strategy in the forage development. ${ }^{4}$ Moreover, $236 \%$ marginal rate of returns produced in the present study, more than the minimum rate of return (40-100\%) which is acceptable to farmers in adopting any agricultural intervention. ${ }^{5}$ 
Table I The effect of different seed sources on forage, seed yields, and quality of Berseem clover

\begin{tabular}{|c|c|c|c|c|c|c|c|c|}
\hline Seed sources & $\begin{array}{l}\text { DM yield } \\
\text { (t/ha) }\end{array}$ & $\begin{array}{l}\text { Forage yield } \\
\text { (t/ha) }\end{array}$ & $\begin{array}{l}\text { Seed yield } \\
\text { (kg/ha) }\end{array}$ & $\begin{array}{l}\text { CP* } \\
(\%)\end{array}$ & $\begin{array}{l}\text { DMD* } \\
(\%)\end{array}$ & $\begin{array}{l}\text { NDF* } \\
\text { (\%) }\end{array}$ & $\begin{array}{l}M E^{*}(\mathrm{M} J / \mathrm{kg} \\
\mathrm{DM})\end{array}$ & $\begin{array}{l}\text { WSC* } \\
\text { (\%) }\end{array}$ \\
\hline Farmer Seed & 5.75 & 43.63 & 186 & 26.34 & 67.38 & 30.12 & 9.93 & 2.559 \\
\hline Market Seed & 6.47 & 49.04 & 204 & 25.61 & 67.27 & 30.53 & 9.87 & 2.653 \\
\hline $\begin{array}{l}\text { Research Station } \\
\text { Seed }\end{array}$ & 8.39 & 60.79 & 580 & 27.13 & 68.97 & 28.72 & 10.13 & 2.815 \\
\hline SED** & 0.51 & 2.95 & 40.13 & 0.81 & 1.45 & 1.24 & 0.1 & 0.28 \\
\hline
\end{tabular}

**SED $=$ standard error of difference

*CP, crude protein; DMD, dry matter digestibility; NDF, neutrant detergent fiber; ME, metabolisable energy; WSC, water soluble carbohydrates

\section{Conclusion}

In conclusion, the RS produced the highest weight of green forage, DM and seed yields of better quality across all farm sites when taken three forage cuts at 65,110 and 150 DAS prior to seed harvest. Moreover, the farmer participatory research approach and the establishment of VBFSE proved to be the realistic approach of bringing positive change at smallholder farmer's level.

\section{Acknowledgements}

We are greatly thankful to Australian Centre for International Agricultural Research (ACIAR) for providing funds to undertake this research project.

\section{Conflict of interest}

Author declares that there is no conflict of interest.

\section{References}

1. Afzal M. Re-designing smallholder dairy production in Pakistan. Pakistan Veterinary Journal. 2010;30:187-190.

2. David S. Farmer seed enterprises: a sustainable approach to seed delivery? Agriculture and Human Values. 2004;21(4):387-397.

3. Amato G, Giambalvo D, Ruisi P. Cut and post-put herbage management affects Berseem clover seed yield. Agronomy Journal. 2013;105:1222-1230.

4. Anwar MZ, Khan MA, Ikram S, et al. Small farmers perceptions regarding improved fodder and forage varieties: results of participatory on farm research. Pakistan Journal of Agricultural Research. 2012;25:295-306.

5. Shah H, Hussain K, Akhtar W, et al. Returns from agricultural interventions under changing price scenario: A case of gypsum application for moisture conservation for wheat production under rainfed conditions in Pakistan. World Applied Sciences Journal. 2011;14(2):363-368. 